Sandor Czegledi

University of Pannonia, Hungary
2020, Vol. 17 (2), 27-45(284)

revije.ff.uni-lj.si/elope

https://doi.org/10.4312/elope.17.2.27-45

UDC: 342.52(73):81'272"1774/1861"

\title{
Nine Decades of Dealing with Diversity: Language-Related Attitudes, Ideologies and Policies in Federal-Level US Legislative and Executive Documents from 1774 to 1861
}

ABSTRACT

The paper examines the shifting orientations towards languages and linguistic diversity in the United States by analysing relevant Congressional and presidential documents from the beginning of the American nation-building experience until the outbreak of the Civil War. The investigation focuses on the legislative activities of the Continental Congress and those of the first thirty-six federal Congresses as recorded primarily in the Journals of the respective legislative bodies. The presidential documents of the first fifteen Chief Executives, from George Washington to James Buchanan, are examined from the same perspective. The results indicate that the most salient language policy development of the post-1789 period was the shift from the symbolic, general language-related remarks towards the formulation of substantive, general policies, frequently conceived in an assimilation-oriented spirit in the context of territorial expansion. Although presidents were considerably more reluctant to address language-related matters than the federal legislature, the need to revise the statutes of the United States was recognised as a presidential priority as early as the 1850 s.

Keywords: United States, Congress, Presidency, language policy, language ideology, pre-Civil War era

\section{Devet desetletij ukvarjanja z raznolikostjo: Jezikovni odnosi, ideologije in politike $v$ ameriških zveznih zakonodajnih in izvršnih dokumentih od 1774 do 1861}

\section{POVZETEK}

Prispevek proučuje spreminjajoče usmeritve $\mathrm{k}$ jezikom in jezikovni raznolikosti v ZDA na podlagi analize ustreznih kongresnih in predsedniških dokumentov od začetka ameriških državotvornih izkušenj do izbruha državljanske vojne. Raziskava se osredotoča na zakonodajne dejavnosti Kontinentalnega kongresa in dejavnosti prvih šestintridesetih Zveznih kongresov, zabeležene predvsem v revijah posameznih zakonodajnih organov. Preučujemo tudi predsedniške dokumente prvih petnajstih predsednikov ZDA, od Georgea Washingtona do Jamesa Buchanana. Rezultati kažejo, da je bil najpomembnejši razvoj jezikovne politike v obdobju po letu 1789 vsesplošni premik od simbolnih, splošnih jezikovnih pripomb k oblikovanju odločilnih, splošnih politik, ki so bile v kontekstu ozemeljske širitve pogosto zasnovane v asimilacijsko naravnanem duhu. Čeprav so bili predsedniki precej bolj zadržani pri obravnavi jezikovnih vprašanj kot zvezni zakonodajalec, je bila potreba po reviziji zakonov v ZDA že v petdesetih letih prejšnjega stoletja prepoznana kot prednostna predsedniška naloga.

Ključne besede: Združene države Amerike, Kongres, predsedništvo, jezikovna ideologija, obdobje pred ameriško državljansko vojno 


\section{Theoretical Introduction}

According to Bernard Spolsky's classic definition, language policy (LP) may refer to "all the language practices, beliefs and management decisions of a community or polity" $(2004,9)$. The first component ("language practices") is defined as the observable behaviours and choices - i.e., what people actually do, what linguistic features are chosen, which varieties of language are used (Spolsky 2009, 4). The second component of language policy consists of beliefs about language, sometimes collectively called "an ideology", while the third component is "language management", i.e. the "explicit and observable efforts" to modify practices or beliefs $(2004,9)$.

"Language ideology" gained recognition as a legitimate component and a worthy area of research within language policy roughly a quarter century after the phrase was introduced by Shirley Brice Heath in 1977. Heath defined the notion as "the self-evident ideas and objectives a group holds concerning the roles of language in the social experiences of members as they contribute to the expression of that group" (qtd. in Galindo 1997, 107). Reynaldo F. Macías argued that "language ideologies" are collective perceptions that may or may not be factually correct $(2000,52)$. More recently, Judith T. Irvine described language ideologies as "conceptualizations about languages, speakers, and discursive practices" (2012). Language ideologies permeate both language practices and various management efforts - consequently, they are reflected in language-related legislative proposals as well.

In David Cassels Johnson's interpretation $(2013,9)$, "a language policy is a policy mechanism that impacts the structure, function, use, or acquisition of language", and includes: 1. official regulations; 2. unofficial, covert, de facto, and implicit mechanisms; 3. processes (policy creation, interpretation, appropriation, and instantiation); 4. policy texts and discourses across multiple contexts and layers of policy activity (influenced by the ideologies and discourses unique to that context). A legislative analysis focusing on the national/federal level may cover a considerable proportion of the aspects listed above, with the likely exception of the unofficial, covert mechanisms and the interpretation, appropriation, and instantiation processes at lower levels. As far as the genesis of policies is concerned, the study of legislative proposals may also provide an occasional direct insight into grassroots demands (i.e. bottomup policy initiatives), since various petitions by minority groups (mostly requesting the translation of federal documents into minority languages) routinely appeared on the agendas of both chambers. Failed or yet-to-be-enacted proposals are also valuable from the researcher's perspective. Joseph Lo Bianco explicitly warns against concentrating solely on declared, or explicit, laws and policy in LP analysis (Lo Bianco 1999, 39), recommending that LP scholars should probe the "subtler realm of convention, beliefs and attitude, culture and tradition" by focusing on language policies "in the making", instead of giving descriptive accounting of policies that "have been made" (1999, 39-40).

Despite providing access mostly to top-down, overt, de jure and explicitly documented policy proposals, one can assume that in a representative democracy legislative proposals (both the enacted and the failed bills and resolutions) reflect the diverse views of the electorate to a considerable degree. In the context of the current examination, this expectation should be accepted only with the caveat that the franchise was extremely limited before the Civil War: 
practically only white, property-owning males had the right to vote (although the property qualifications were gradually lowered and basically eliminated by the 1850s). Consequently, the opinions and beliefs about the proper societal role of the majority language and those of the minority tongues reflected the perspectives of this dominant class, as African-Americans and women were excluded from political decision-making. Furthermore, citizens were able to exercise even less influence over the Senate than they can today, as Americans did not directly vote for senators before the ratification of the 17th Amendment in 1913. Consequently, the US House of Representatives (with members elected for two-year terms) has always been more responsive to the short-term attitude swings of the population than the Senate, whose members are under considerably looser voter control with their six-year terms in office. In practical terms, the more or less direct influence of the people extends only to the "first branch" of government (the legislative) and to the executive as far as the Chief Executive and Vice President are concerned. Traditionally, there has never been a separate federal agency in the United States charged with LP-related research, resource allocation or decision-making. (For the abortive attempt to establish a Language Academy, see 4.1.3.)

This research focuses on the documents of those federal-level actors and agents that potentially recorded (the shifts in) popular language ideologies before 1861. State- and municipal-level language-related political struggles during this period were recorded and analysed in depth by Heinz Kloss in his classic book The American Bilingual Tradition (Washington, D.C.: Center for Applied Linguistics [1977] 1998), especially in chapters 5 and 6 (107-93).

The preliminary findings indicate an assimilationist shift in the frequently ad hoc language policies of the United States by the early 1800s, which was triggered by continued territorial expansion (with the perceived need to Americanise the new inhabitants as quickly as possible) and budgetary constraints (which resulted in the discontinuation of the minority-language editions of laws and other federal documents.)

\section{Aims and Corpora}

The present paper examines the shifting orientations towards languages and linguistic diversity in the United States as reflected in relevant Congressional and presidential documents from the beginning of the American nation-building experience (here understood as the convening of the first Continental Congress in 1774) until the outbreak of the Civil War (1861). Efforts are made to keep track of symbolic statements (which reflect "ideological" views and opinions) and substantive proposals (which belong to the field of "language management" according to Spolsky's categorisation). By focusing on the role of the federal legislature both as a language policymaking agent and as an indicator of language ideological trends, the present investigation strives to be multidisciplinary and meet the expectations of the latest "empirical turn" in LP research (Johnson and Stephens 2018, 814-15).

The corpora of the current analysis were built with the help of the online legislative database of the Library of Congress ("A Century of Lawmaking for a New Nation", https://memory. loc.gov/ammem/amlaw/) and that of "The American Presidency Project" database (https:// www.presidency.ucsb.edu/, see Wooley and Peters n.d.), which contains the messages and papers of all American Presidents in a searchable format. The online keyword search carried 
out from January 2018 to June 2019 focused on all the presidential and Congressional documents that contained the words "language" and/or "languages" in the specified 87-year period. After removing the irrelevant instances (which referred to, for example, the particular choice of words by an individual), 16 presidential and 236 legislative documents remained with at least one relevant language-related reference. The relevant records of the executive corpus ("ExCorp" for short) contained only 16 relevant documents - consequently, it was not justifiable to divide it any further.

The legislative corpus ("LegCorp"), on the other hand, was subdivided into three subcorpora to make comparison and contrast possible over time and across markedly different historical periods.

Legislative Corpus 1 (LegCorp 1) includes records from the following documents:

- The Journals of the First and Second Continental Congress (hereinafter cited as JCC) (from September 5 to October 26, 1774, and from May 10, 1775, to March 2, 1789, respectively);

- The Letters of Delegates to Congress, 1774-1789 (written by delegates during their years of actual service in the First and Second Continental Congress);

- The Records of the Federal Convention of 1787;

- The Debates in the Several State Conventions on the Adoption of the Federal Constitution (from September 1787 to March 1789), compiled by Jonathan Elliot; and

- The Federalist Papers (written between October 1787 and May 1788).

LegCorp 2 (March 4, 1789 to March 3, 1815), from the first through the thirteenth US Congresses, contains records from:

- House Journal (hereafter cited as HJ);

- the Senate Journal (SJ);

- the Senate Executive Journal (SEJ);

- Maclay's Journal (MJ) (the journal of William Maclay, United States Senator from Pennsylvania, 1789-1791); and

- the Annals of Congress (AC).

LegCorp 3 covers the longest historical period, from the conclusion of the "Second War of Independence" ("War of 1812") in 1815 to the end of the 36th Congress in early 1861. The documentary sources include:

- House Journal (HJ);

- the Senate Journal (SJ);

- the Senate Executive Journal (SEJ); and

- the United States Statutes at Large (Stat.), which is an official compilation of the Acts and Resolutions of Congress. 


\section{Method}

In order to separate ideological statements from management efforts - while, at the same time, be able to gauge the likely impact of the given proposals - I have constructed a simple yet potentially helpful and effective "Language Policy Spectrum Framework" (LPSF) to classify the corpus data.

TABLE 1. The "Language Policy Spectrum Framework" (LPSF).

\begin{tabular}{|l|l|l|}
\hline & "Ideology" & "Management" \\
\hline & Symbolic remarks/proposals & Substantive proposals \\
\hline General & $\begin{array}{l}\text { simple/concurrent resolutions, } \\
\text { ideological remarks }\end{array}$ & $\begin{array}{l}\text { "Language Policy" } \\
\text { (bills; joint resolutions) }\end{array}$ \\
\hline Specific & $\begin{array}{l}\text { ideological remarks, } \\
\text { (simple/concurrent resolutions) }\end{array}$ & $\begin{array}{l}\text { bills, resolutions affecting one L } \\
\text { or an individual in a particular } \\
\text { situation } \rightarrow \text { no precedential value }\end{array}$ \\
\hline
\end{tabular}

The two quadrants on the left represent symbolic policies and remarks, defined in the public policy context by James E. Anderson as policies that "have little real material impact on people"; "they allocate no tangible advantages and disadvantages"; rather, "they appeal to people's cherished values" (Anderson 2003, 11). On the other hand, substantive policies (the right quadrants) "directly allocate advantages and disadvantages, benefits and costs" $(2003,6)$.

The "general" vs. "specific" criteria hinge on the scope of the policy, statement, or opinion in question. Here, (substantive) national-level policies or sweeping, stereotypical (symbolic) statements or personal opinions about, for example, the perceived nature, potential or usefulness of certain languages are considered to be "general". On the other hand, (local) policy decisions affecting a single language in a particular situation (e.g. whether to purchase Latin dictionaries for Congress) or a single individual (e.g. a translator's position or pay) are classified as "specific". Policies that were applied to entire territories and/or future states were regarded as simultaneously "specific" and "general", given the overall national or federal-level perspective of the analysis. Today's most controversial, national-level LP-related laws, proposals, executive orders, and regulations (including, for instance, the provision of multilingual ballots, the federal-level officialisation attempts and Executive Order 13166) belong to the top right quadrant; therefore, they are "substantive" and "general" in nature. In a narrow sense, this quadrant contains what may be regarded as genuine management or policy efforts, especially if enacted into law.

Another practical, easily applicable yet highly informative framework for formal LP analysis has been developed by Terrence G. Wiley since the late 1990s (Wiley 1999, 21-22; Wiley and de Korne 2014, 1-2). Wiley classifies the full range of possible policies according to a spectrum of categories containing a promotion-, expediency-, tolerance-, restrictionor repression-orientation. Promotion means the allocation of resources to support the (official) use of (minority) languages, while expediency amounts to no more than shortterm minority language accommodations - e.g. the provision of court interpreters, bilingual 
ballots, transitional bilingual education - which are not intended to foster minority-language maintenance (Johnson 2013, 35). (This analysis regards translation and interpretation as expediency-oriented policies.) Wiley's classification is especially useful to determine how particular languages were treated in different (e.g. "minority" vs. "foreign") contexts.

\section{Findings}

Due to spatial constraints, a brief summary of each examined period follows with the tendencies and preliminary conclusions that were found with the help of the application of the LPSF. For the sake of brevity, only the most characteristic opinions or policy proposals associated with each quadrant are discussed in detail.

\subsection{Presidents and Linguistic Diversity before 1861}

In general, presidents were extremely reluctant to address language-related matters directly: they especially avoided involvement in substantive, general issues.

TABLE 2. Distribution of LP-references in the entire presidential corpus (1789-1861). (The bold numbers in the central rectangle indicate the total number of references; the shaded fields below them show the most significant language in the given quadrant; while the remarks at the bottom of each quadrant refer to the 2 nd, 3 rd, etc. most important language, policy or reference. E=English; Plain E=Plain English; FLs=foreign languages; Fr.=French; Sp.=Spanish)

\begin{tabular}{|c|c|c|c|c|}
\hline \multirow{5}{*}{ General } & Symb & & \multicolumn{2}{|c|}{ Substantive } \\
\hline & \multicolumn{2}{|c|}{$\begin{array}{l}\text { E unifies the US (and enables the } \\
\text { settlement of debates with GB) }\end{array}$} & \multicolumn{2}{|c|}{ Plain E in govt. documents } \\
\hline & \multirow{3}{*}{\multicolumn{2}{|c|}{ Human Ls are imperfect (4) }} & 2 & \\
\hline & & & Plain $\mathrm{F}$ & \\
\hline & & & $\begin{array}{l}\text { as prob } \\
\text { to join }\end{array}$ & $\begin{array}{l}\text { in Cuba } \\
\text { US?) } 1\end{array}$ \\
\hline \multirow{4}{*}{ Specific } & & & \multicolumn{2}{|c|}{ Copies of specific treaties in FLs } \\
\hline & 0 & & 5 & \\
\hline & & & Fr. 4 & \\
\hline & & & Sp. & \\
\hline
\end{tabular}

The very first language-related remark in the ExCorp was made by George Washington in 1796. He referred to a specific (but substantive) situation: the English translation of the French- and Spanish-language documents related to Pinckney's Treaty (Washington 1796).

\subsubsection{Symbolic, General Statements}

Symbolic references were dominated by the English language (five records). All of these remarks were general, stereotypical statements: mostly optimistic observations about the successful unifying and nation-building role of the English language at home; in addition to its key foreign policy function to cement an early form of special relationship with Great Britain. 
A classic example of the former category was James Monroe's characterisation of the American people, described as

descended from the same ancestors, speaking the same language, having the same religion and universal toleration, born equal and educated in the same principles of free government, made independent by a common struggle and menaced by the same dangers, ties existed between them which never applied before to separate communities. (Monroe 1822)

The linguistic common bond with Great Britain was considered helpful in settling issues stemming, for example, from the ill-defined northeastern boundary with the British-held Canadian territories (Jackson 1834). Prior to the Civil War, several Chief Executives had complained about the imperfect nature of human language (including the language of the Constitution), which necessitated the judicial interpretation of the basic law from time to time. The symbolic, specific quadrant remained empty during the examined period.

\subsubsection{Substantive, Specific Policies}

These records mostly focused on the translation of treaties into English and/or French (or Spanish). Indicating already-existing practices, they cannot be considered as new policy proposals.

\subsubsection{Substantive, General Policies}

The only (and most far-reaching) general policy proposal came from Millard Fillmore in 1851, who proposed the revision of US statutes "not only be made accessible to all, but be expressed in language so plain and simple as to be understood by all and arranged in such method as to give perspicuity to every subject" (Fillmore 1851). This (by now forgotten) moment could be regarded as the birth of the Plain English Movement at the federal level, although the actual name was born later. At the management level, Fillmore also recommended the appointment of a commission "to revise the public statutes of the United States, arranging them in order, supplying deficiencies, correcting incongruities, simplifying their language" (Fillmore 1851). However, the Revised Statutes of the United States appeared only in 1874 - almost a quarter century after the first presidential initiative (see 4.4.4).

In sum, the results show that language had practically been a nonissue before the 1850 s as a presidential policy concern. Genuine language policy involvement by the Chief Executive started in 1851, with Millard Fillmore's early Plain English proposal. Although both John Adams and Thomas Jefferson are said to have criticised the verbosity and overcomplicated syntax of contemporary legal language (Tiersma, n.d.), neither of them endorsed official policy initiatives to remedy the situation. Earlier, John Adams (working as the US diplomatic representative in Holland in 1780) even proposed setting up an American Language Academy "for correcting, improving, and fixing the English Language..., [which would] Strike all the World with Admiration and Great Britain with Envy" (Adams Papers Digital Edition 2019). However, the Continental Congress did not react to the suggestion, and the idea never surfaced in either executive or legislative documents again. 


\subsection{LegCorp 1: Language(s) and the Continental Congress (1774-1789)}

The chosen documents in this period, which included several 'critical' years for the survival of the US, contained 54 records with either symbolic or substantive LP relevance.

TABLE 3. Distribution of LP-references in the 1774-1789 legislative corpus. (The bold numbers in the central rectangle indicate the total number of references; the shaded fields below them show the most significant language in the given quadrant; while the remarks at the bottom of each quadrant refer to the 2 nd, 3rd, etc. most important language, policy or reference. $\mathrm{E}=$ English; N. Am.=Native American languages; Ger.=German; Fr.=French; Sp.=Spanish; FLs=unspecified foreign languages.) (Source: author.)

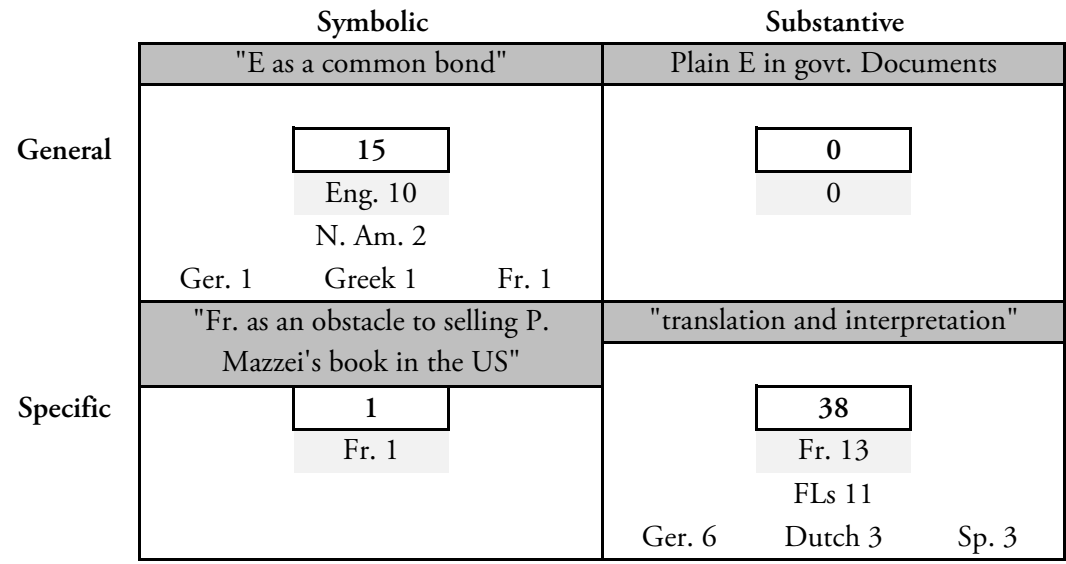

\subsubsection{Symbolic, General Statements}

Even a casual glance reveals that throughout the examined period "foreign languages" (FL) dominated the relevant discourses, and the English language consistently appeared in the symbolic, general quadrant, cast in the role of a/the most important social glue in American society. Moreover, the English language emerged naturally after the Revolutionary War as a straightforward bridge towards rapprochement with Great Britain. As put by Charles Pinckney in August, 1786: "Though the animosities of Great Britain are still warm . . . when the present differences shall have terminated, it will ever be her interest to be closely connected. Our language, governments, religion and policy, point to this" (JCC 1786: 31, 936).

\subsubsection{Symbolic, Specific Reference}

Thomas Jefferson's Italian friend (and American agent) Philip Mazzei sent to the United States 164 copies of his four-volume magnum opus titled Recherches historiques et politiques sur les Etats-Unis [A Political History of the American Revolution]. The book, however, did not sell, and James Madison had to acknowledge to Mazzei that "the French language is the greater obstacle" to such success (Letters of Delegates, 1778: 25, 415). 


\subsubsection{Substantive, Specific Examples}

In this quadrant, the French language and (unspecified) "foreign languages" assumed centre stage, mostly in the context of translation and interpretation. Additionally, this quadrant witnessed an early form of soft power projection: Congress sent several letters (in French) to the "Oppressed Inhabitants of Canada", trying to persuade them to join the American fight for independence and individual rights (JCC 1775: 2, 69-71).

In addition to French, Spanish, and other foreign languages, references to German and Dutch also appeared in the "substantive, specific" quadrant. The German language featured as a foreign policy (propaganda) tool, and also appeared in the context of short-term, expediency-type accommodations towards the German minorities living in the United States. Congress authorised the German translation of the "late treaty between the Courts of London and Hesse, for troops to be employed in America" (JCC 1776: 6, 984), and actively encouraged German mercenaries in the service of Great Britain to switch sides and "rise into the rank of free citizens of free states" - offering future defectors free land, oxen, and hogs as material incentives (JCC 1778: 10, 403). Heinz Kloss mentions further examples when Congress commissioned the translation of certain documents into German from as early as 1774: the "Excerpts from the Deliberations of the American Continental Congress Held in Philadelphia"; circular letters; declarations; and reports from 1775-78, including the most important publication of the period, the German edition of the Articles of Confederation (Kloss [1977] 1998, 26-27). From 1780 onwards, however, Congress issued no further German publications, "the reasons for which are unknown" (Kloss [1977] 1998, 27). On September 13, 1779, the translation of "a circular letter from Congress to their constituents" was cancelled (JCC 1779: 15, 1052-62). Following this date, no references to German translations can be found in the examined period.

\subsubsection{Substantive, General Policies}

In many respects, the most important field in the framework is the empty top right quadrant, which means that no general, substantive LP initiatives (i.e. national-level policies or initiatives) were recorded in the examined documents between 1774 and 1789. If we try to answer the question 'When did conscious, proactive, national-level language policymaking start in the US?' we will have to look further ahead in time.

\subsection{LegCorp 2: Language(s) and the US Federal Congress before 1815}

LegCorp 2 contains approximately 45 elements with either symbolic or substantive LP relevance. (Legal proposals binding for entire territories or states were considered to be general and specific at the same time.) Language-related legislative discourses were dominated by minority and foreign languages during the examined period. English was given relatively little attention, while classical languages and Native American languages were not mentioned at all, despite the federal government's continued policy to buy Indian lands, to 'civilise' the inhabitants - and to wage wars that culminated in Tecumseh's Rebellion in the 1810s. Apparently, no LP-ramifications of these conflicts can be identified today, relying on the records of the Federal Congress alone. 
TABLE 4. Distribution of LP-references in the 1789-1815 legislative corpus. (The bold numbers in the central rectangle indicate the total number of references; the shaded fields below them show the most significant language in the given quadrant; while the remarks at the bottom of each quadrant refer to the 2nd, 3rd, etc. most important language, policy or reference. E=English; Fr.=French; Sp.=Spanish; Ger.=German; FLs=unspecified foreign languages; Min. L=minority language.) (Source: author.)

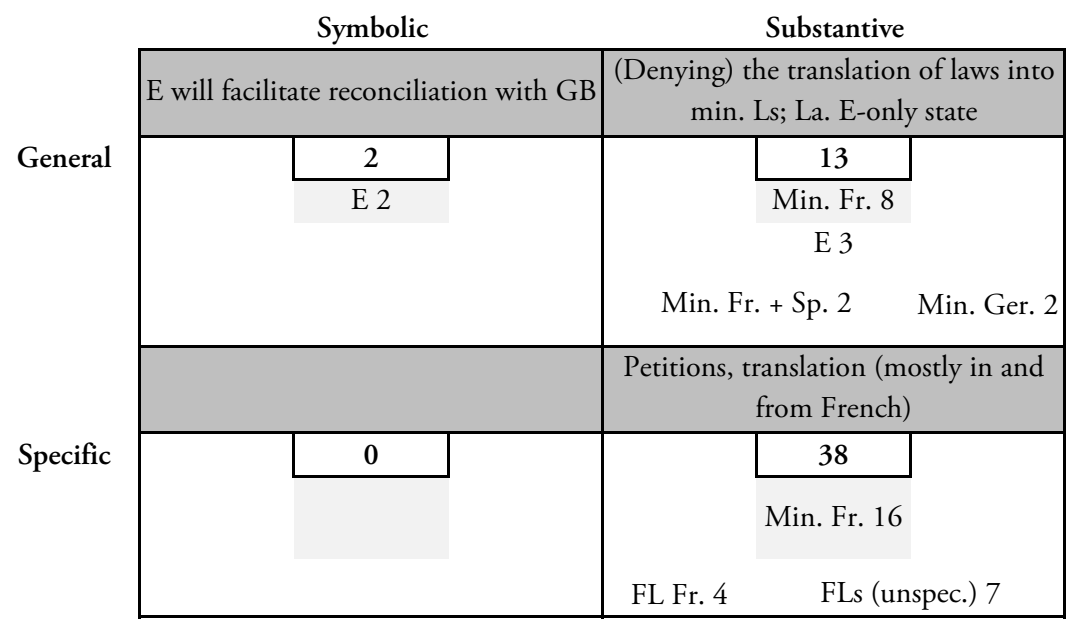

\subsubsection{Symbolic, General Remarks}

The two symbolic remarks by Pennsylvania Senator William Maclay echoed the frequent, optimistic expectations about rapprochement with Great Britain: "ours was a civil war with Britain, and that the similarity of language, manners, and customs will, in all probability, restore our old habits and intercourse, and that this intercourse will revive... our ancient prejudices against France" (MJ, Ch. XVI, 1791, 407). Maclay was extremely prescient in his predictions, as the "Quasi-War" with France would prove him right in a few years' time.

Symbolic, specific opinions were not recorded in this period.

\subsubsection{Substantive, Specific Policies and Practices}

LegCorp 2 is dominated by substantive references and proposed policies (although the vast majority were rejected or postponed indefinitely). The specific quadrant contains the translations of treaties and diplomatic messages in addition to petitions coming from language minorities asking for the translation of (at least some of) the laws of the US into minority languages. These petitions were routinely rejected or postponed indefinitely, although several, similar requests were introduced later - only to meet the same fate. The 1794 petition by "a number of Germans, residing in the State of Virginia [...] praying that a certain proportion of the laws of the United States may be printed in the German language" (HJ 1794, Jan. 9, 31) appeared in the House Journal twice (the second time on Nov. 28) but was rejected after a tied vote, which may have been broken by the Speaker, Frederick Augustus Conrad Muhlenberg (Kloss [1977] 1998, 28). This attempt was not unique: a similar French petition was rejected in 1809, and a few likeminded, unsuccessful German attempts were to be made 
again, such as in 1835 (also resulting in an initial tie vote), then in 1843 and 1862 (Kloss [1977] 1998, 29-33). Perhaps partly due to the persistence of German minorities and the propaganda machinery of the Fatherland, the Muhlenberg-incident was later blown out of proportion, giving rise to fanciful tales about the German language almost displacing English as the official language of the United States.

\subsubsection{Substantive, General Policies}

Following the Louisiana Purchase (1803), the territorial expansion of the US put language issues in focus once again, this time in the context of integrating the territories into the US (much against the will of the Creoles, Cajuns, Native Americans and other inhabitants). The Louisiana Purchase Treaty of 1803 (see US National Archives \& Records Administration 2019) guaranteed that the inhabitants of the ceded territory

shall be incorporated in the Union of the United States and admitted as soon as possible according to the principles of the federal Constitution to the enjoyment of all these rights, advantages and immunities of citizens of the United States, and in the mean time they shall be maintained and protected in the free enjoyment of their liberty, property and the Religion which they profess. (Louisiana Purchase Treaty, Art. III)

Language rights, however, were not mentioned explicitly, and as it turned out, they were in practice denied for years to come. Louisiana was divided along the 33rd parallel into the (strategically more important) "Orleans Territory" (corresponding roughly to the presentday state in terms of geographical location) and the rest of the area became the "District of Louisiana" (later "Louisiana Territory," then "Missouri Territory" after 1812). In response to the heavy-handed policies of the federal government, which included the appointment of an English-speaking governor with dictatorial powers, the inhabitants of Orleans Territory sent to Congress the list of their grievances in the form of the "Louisiana Memorial" of December 1804 (also known as Louisiana Remonstrance; see Derbigney 1804). The drafters of the document protested against the "introduction of a new language into the administration of justice, the perplexing necessity of using an interpreter for every communication" (aggravated by the contemporary coexistence of French, Spanish and American legal practices), and "the sudden change of language in all the public offices" (Louisiana Memorial). These protests fell on deaf ears in Congress, yet as the population grew, a more representative government system was set up according to the principles laid down by the Northwest Ordinance of 1787. Nevertheless, when Louisiana was admitted as a regular state in 1812 on the basis of the Enabling Act of 1811, its first constitution was written in the spirit of English-only, specifying that "All laws [...] and the public records of this State, shall be promulgated, preserved and conducted in the language in which the constitution of the United States is written" (Kloss [1977] 1998, 112), despite the fact that "a strong French majority still existed" in the state at the time. Nevertheless, the 1845 state constitution was to recognise the French language as quasi-co-official, but this magnanimity disappeared after the Civil War, only to return briefly after 1879. (For a more in-depth analysis see e.g. Kloss [1977] 1998, 107-15.)

Similarly to the Germans, the French also tried to ask Congress to provide for the translation of the laws into their language. The petition of 1809 by the French-speaking inhabitants of 
the Territory of Michigan almost succeeded: it was passed by the Senate (AC, 10th Cong., 2nd Sess., Senate, x), but was eventually rejected by the House (AC, 10th Cong., 2nd Sess., House, xxxv; AC, 11th Cong., 1st Sess., House, lxxiii).

Overall, the substantive, general proposals in LegCorp 2 promoted English and restricted minority languages: these were the major themes of the initiatives with the greatest real or potential impact. The substantive, specific practices and policies were predominantly expediency-oriented, focusing on the financing of translation and interpretation services, mostly affecting the French language, but only in a "foreign language" context. Expediency no longer extended to the provision of short-term, transitional minority-language accommodations.

\subsection{LegCorp 3: Language(s) and the US Federal Congress between 1815 and 1861}

LegCorp 3 is based on the longest period (spanning 46 years and 23 Congresses altogether); consequently it includes the highest number of relevant records, more than 130 . The substantive, specific quadrant turned out to be the busiest one here as well; and there emerged significant substantive, general policies, too - indicating that the governmental noninvolvement which characterised the pre-1789 period was indeed over.

TABLE 5. Distribution of LP-references in the 1815-1861 legislative corpus. (The bold numbers in the central rectangle indicate the total number of references; the shaded fields below them show the most significant language in the given quadrant; while the remarks at the bottom of each quadrant refer to the 2nd, 3rd, etc. most important language, policy or reference. E=English; Plain $\mathrm{E}=$ Plain English; N. Am.=Native American languages; Ger.=German; Fr.=French; Sp.=Spanish; FLs=unspecified foreign languages; Min. L=minority language.) (Source: author.)

\begin{tabular}{|c|c|c|c|c|c|}
\hline \multirow{5}{*}{ General } & \multicolumn{2}{|r|}{ Symbolic } & \multicolumn{3}{|c|}{ Substantive } \\
\hline & \multicolumn{2}{|c|}{$\begin{array}{l}\text { Human } \mathrm{L} \text { is imperfect; } \mathrm{E} \text { as a } \\
\text { common bond (with GB, TX) }\end{array}$} & \multicolumn{3}{|c|}{$\begin{array}{c}\text { Duty-free importation of FL books; } \\
\text { Plain E }\end{array}$} \\
\hline & & 21 & \multirow{4}{*}{\multicolumn{3}{|c|}{$\begin{array}{c}\text { Plain E } 6 \\
\text { Class. Ls } 3 \quad \text { Min. Ls } 2 \\
\text { Translating documents; petitions in } \\
\text { Min. Ls; duty-free Bibles }\end{array}$}} \\
\hline & & E 8 & & & \\
\hline & & Human L & & & \\
\hline \multirow{6}{*}{ Specific } & FL Sp. 3 & N. Am. 3 & & & \\
\hline & \multicolumn{2}{|c|}{$\begin{array}{l}\text { Letters and pamphlets in French; N. } \\
\text { Webster's lecture in Congress }\end{array}$} & \multicolumn{3}{|c|}{$\begin{array}{l}\text { Translating documents; petitions in } \\
\text { Min. Ls; duty-free Bibles }\end{array}$} \\
\hline & & 5 & & 83 & \\
\hline & & FL Fr. 3 & & Sp. 2 & \\
\hline & & E 1 & & Fr. 18 & \\
\hline & & FLs 1 & E 12 & Ger. 12 & FLs 12 \\
\hline
\end{tabular}

\subsubsection{Symbolic, General Remarks}

These documents also contain presidential (State of the Union) messages that mentioned "language", in the symbolic, general context of "imperfection" and the (hopefully improving) 
US-British relationship. Additionally, the "common bond" theme appeared in the discussions about the possible annexation of Texas, whose "civilized inhabitants" were described by Andrew Jackson as "emigrants from the United States" who "speak the same language [...] cherish the same principles, political and religious" (HJ 1836, Dec. 22, 105-6). John Tyler used similar arguments in 1843 (SJ 1843, Dec. 5, 11).

\subsubsection{Symbolic, Specific Instances}

The symbolic, specific quadrant contains letters and pamphlets presented in Congress in foreign languages (mostly in French). (Petitions are considered to be substantive, so they are discussed in those quadrants.) One symbolic example is "A communication, in the French language, from Mons. Fontaneille, upon the subject of the production of silk; which was referred to the Committee on Agriculture" (HJ 1831, Feb. 25, 360). The English language appears in this quadrant once: the Hall of the House of Representatives was granted to Noah Webster, "author of the American Dictionary, to deliver a discourse... on the origin, history, and present state of the English language" (HJ 1830, Dec. 31, 122).

The Senate Journal also recorded a symbolic gesture by an alleged Hungarian professor, a certain "Dr. Gabor Naphegyi", who wrote a "manuscript tribute, in fourteen different languages, to the memory of Zachary Taylor, late President of the United States" (SJ 1850, July 22, 465). Naphegyi, who was originally a Bohemian conman called Sonnenberg, had successfully ingratiated himself with powerful politicians, including the President of the United States, sometimes by posing as the private secretary of the exiled revolutionary leader of Hungary, Louis Kossuth (who did not know him) (Wells 2017, 21). Nevertheless, Naphegyi's language skills helped him to continue his career as a swindler for decades.

\subsubsection{Substantive, Specific Practices and Policies}

The substantive, specific quadrant was dominated by Spanish-language petitions, proposals and documents, which was the effect of the territorial expansion of the United States, marked by the Adams-Onís Treaty (1819), the transfer of Florida under US authority, the annexation of Texas, the Mexican War (1846-48), and the Treaty of Guadalupe Hidalgo (1848).

In this context, the inhabitants of the Territory of Florida sent a petition to Congress in 1829, "praying that counsel, learned in the Spanish law and language, may be appointed to protect their rights, and to plead in their behalf, before the tribunal appointed to try and determine their titles to land" (HJ 1829, Feb. 9, 263). (The petition was referred to a committee, and never surfaced again.) Nevertheless, the Clerk of the House did employ a French and Spanish translator to work for the House and the Land Office, whose tenure was ended after two years (HJ 1837, Jan. 24, 277). On the other hand, petitions to translate presidential messages into Spanish were rejected, as it routinely happened to similar requests by other minority groups.

The French language dominated the diplomatic context, and translations of documents and agreements frequently appeared on the agenda. One specific subfield was associated with the translation of relevant French documents associated with the "French Spoliation Claims," by which thousands of American citizens sought compensation - many years after the actual 
conflict - from the federal government for the loss of ships and cargoes during the Quasi-War with France (1797-1801) (HJ 1836, Feb. 3, 287). Another area where the French language appeared (this time as a minority tongue) was the question of land titles on the territory of the former Louisiana Purchase. The year 1818 witnessed the filing of an individual (HJ 1818, Jan. 23, 173) and a group petition (HJ 1818, March 14, 331) in which the inhabitants requested (in French) the confirmation of their land titles on the said territory. In May 1820, Congress appointed commissioners "for ascertaining and deciding on the rights of persons claiming lands in the district of Detroit", who were also authorised to employ "a person capable of translating the French language, as an agent" (Stat. 16th Cong., 1820, May 11, 572). Just as in the case of the Spanish language land claims (see above), Congress endorsed very narrowly defined (and temporary) expediency-oriented language rights in the early 19th century. Nevertheless, as James Crawford notes, proving titles to holdings in Englishspeaking courts could be an extremely costly affair: over a generation, the Spanish-speaking gentry in California lost title to virtually all of the large haciendas in order to be able to pay the legal fees in the wake of the California Land Act of 1851 (Crawford 2000, 14). Despite granting some minority-language access rights in the case of land title confirmations, French translation requests of State of the Union Addresses were denied in 1843 (HJ 1843, Dec. 18, 63 ) and in 1849, too (HJ 1849, Dec. 24, 169).

References to the German language are typically found in the minority language context, in proposals which tried to extend (practically non-existent) language rights in limited circumstances. These usually included repeated requests to translate the president's annual message into German (in 1843, 1844, 1845, 1849, 1850, 1851). Almost all of these were either denied or tabled, which, eventually, meant the same fate for the proposal. The only exception happened in 1849, when 5,000 copies of Zachary Taylor's annual message were allowed to be printed in the German language at the proposal of Mr. Sweetser (HJ, 1849, Dec. 24, 169). No justification for this unique decision was recorded in the Congressional documents, but perhaps the arrival of thousands of German "Forty-Eighters" after the failed revolutions influenced the mindset of legislators - albeit temporarily. The 1854 translation requests concerning the agricultural Patent Office report and the abstract census report also failed to gain the approval of the Federal Legislature (HJ 1854, Jan. 3, 159).

German language rights were realised only in an extremely limited micro-context in 1860 . The "Act to Regulate the Carriage of Passengers in Steamships and Other Vessels" prohibited officers or crew members from visiting "any part of such ship or vessel assigned to emigrant passengers, except by the direction or permission of the master or commander of such ship or vessel" (Stat., 36th Cong., 1st Sess., 1860, March 24, 3). This information was to be posted as a written or printed notice in the English, German and French languages in several parts of the ship (1860, March 24, 34).

References to the English language in the substantive, specific quadrant were mostly associated with Noah Webster's petition in 1824, in which he asked for the duty-free importation for five years of his Dictionary of the English Language and of Synopsis of Languages, as no printing office had all the necessary types in the US (HJ 1824, Dec. 27, 80). Eventually, Congress agreed to a reduced rate, as was "imposed on books of foreign languages" (Stat., 18th Cong., 
2nd Sess., 1825, March 3, 330). Although the decision was not as generous as Webster had hoped it to be, the contemporary duties on imported English-language books were considerably higher than the ones on foreign-language materials.

Since the mid-1810s, the Bible Society of Philadelphia had also been trying to import, free of duty, stereotype plates for printing sacred texts in foreign languages, as well as Bibles $(\mathrm{HJ}$ 1816, Feb. 24, 392). Although the request was granted by the House in 1818 (HJ 1818, Jan. $27,186)$, it eventually died in the Senate.

\subsubsection{Substantive, General Policies}

As it had been the case before, substantive, general proposals represented the genuinely "language management"-oriented policy initiatives of the examined subcorpus. Here, the ubiquitous debates about duties on foreign imports affected printed materials in different languages to a varying degree. In 1819, Congress declared "free of duty books printed in foreign languages" (HJ 1819, Feb. 26, 320). In later revenue laws, the rates fluctuated from time to time, but generally, foreign language publications were allowed to be brought into the US at a lower rate than English language publications.

The most significant, forward-looking and long-term trend-setting language policy initiative of the period was the attempt to simplify legal English. The examination of presidential documents reveals that the first (and only) pre-Civil War Chief Executive who endorsed the idea officially was Millard Fillmore in 1851 (see 4.1). His ally in the legislature, Massachusetts Senator Charles Sumner, introduced similar resolutions from 1852 onwards:

Resolved, That the Committee on the Judiciary be directed to consider the expediency of providing by law for the appointment of a commissioner to revise the public statutes of the United States, to simplify their language, to correct their incongruities, to supply their deficiency, to arrange them in order, to reduce them to one connected text, and to report them thus improved to Congress for its final action, to the end that the public statutes, which all are presumed to know, may be in such form as to be more within the apprehension of all. (SJ 1852, Apr. 8, 332)

Sumner's motives behind the resolution stemmed from his historical knowledge (being familiar with the cumbersome nature of ancient Roman laws) and the fact that very few public (let alone private) libraries in the US could afford to buy the entire set of twelve volumes of the country's statutes (Sumner and Hoar 1900, 3). Thus, the need to reduce them in size (and make them easier to read) served both practical purposes and democratic expectations. Yet, despite presidential support and the fact that "the resolution attracted attention at the time", the Committee on the Judiciary (to which it was referred) did not react to the proposal $(1900,2)$. Sumner continued the arduous legislative battle for the passage of the resolution during the forthcoming years, but success came only after Abraham Lincoln (then Andrew Johnson and Ulysses S. Grant) had endorsed the idea (1900, 4-5). Eventually, Sumner did not live to see the enactment of the Revised Statutes of the United States in 1874. Nevertheless, his efforts paved the way for today's Plain English struggles, an important achievement of which was the signing of the Plain Writing Act into law by Barack Obama in 2010. Despite 
his tenacious - and, eventually, successful - fight for plain and simple legal language use, Charles Sumner's name is now routinely omitted from articles and books focusing on the history of the Plain English Movement.

Minority language rights were given only insignificant protection in the substantive, general quadrant. An amendment to the "Act to Reduce and Modify the Rates of Postage" stipulated that the list of "uncalled-for" (unclaimed) German letters be published "in the German newspaper having the largest circulation in the vicinage" (HJ 1852, July 12, 880). The final, enacted version of the bill dropped "German," and substituted "foreign" instead: "when a list of uncalled-for letters shall be published in any foreign newspaper in any foreign language, said list shall be published in such newspaper having the largest circulation within the range of delivery of said office" (Stat., 32nd Cong., 1st Sess., 1852, Aug. 30, 40).

Finally, the substantive, general proposals also included abortive suggestions that were nevertheless harbingers of future federal policies. In 1818, a petition from a Baptist Association requested the adoption of policies "best calculated to promote the welfare and civilization of the Indian tribes", including "the education of their children in the English language" (HJ 1818, Nov. 19, 21). Although this particular petition never surfaced again in the legislative records, Congress passed the Civilization Fund Act in 1819, with the aim of assisting missionary societies in establishing schools for the assimilation of Native Americans (Prucha 2000, 33). Another restrictive, assimilation-oriented petition from 1838 targeted immigrants in a truly nativist fashion. The so-called "Native American Association" (proponents of white Anglo-Saxon Protestant superiority and immigration restriction) complained that "a large portion of the power of this Government is in the hands of adventurers from every clime, before they have had time to acquire a knowledge of our language, and before they have learned the first principles of a republican Government" (HJ 1838, Jan. 8, 235). As a possible remedy, the organisation recommended "to repeal the acts now in force providing for the naturalization of foreigners, or so to modify the said acts [...] to secure to the native citizens of the United States the full enjoyment of the privileges and rights which they are justly entitled to" (HJ 1838, Jan. 8, 235). Ultimately, these policy proposals were implemented several decades later, with the exclusion of Asian immigrants and the passage of the Immigration "Quota" Acts of the 1920s.

\section{Conclusion}

The proposed Language Policy Spectrum Framework (LPSF) has proved to be an effective tool to visualise ideological remarks, opinions, specific and general policies for longterm comparison and contrast, despite the great amount of data involved in the process. Although a legislative analysis focusing on the federal/national level reveals little about the actual interpretation and appropriation of policies at state and local levels, the enhanced representativeness of the corpora (practically reaching $100 \%$ in this regard) may compensate for the relatively narrow focus of the exploration.

The LPSF can easily separate symbolic and substantive policies. In the US federal context, a legislative proposal can be introduced in either House in four forms: as a bill (public or private), a joint resolution, a concurrent resolution, or a simple resolution. Concurrent and 
simple resolutions are normally not legislative in character, since they are used merely for expressing "facts, principles, opinions, and purposes" of the two Houses (Johnson and Warner 2003, 5-8). Consequently, they are considered to be symbolic only - nevertheless, they are important for mapping the language ideological background of the actual period. The danger of accidental, subjective interpretation is greater in the "general" vs. "specific" context. Here, a more careful deliberation is needed in certain cases, but those instances mostly belong to the "symbolic" category, not affecting the "policy"- or "management"-related conclusions.

Overall, Chief Executives were not particularly eager to get involved in language-related matters before 1861 - yet when Millard Fillmore decided otherwise in 1851, he laid the foundations of a policy which was revived 120 years later and now "makes it easier for the public to read, understand, and use government communications" even today (plainlanguage.gov).

It is not surprising that the English language was frequently seen as a nation-building tool and a key foreign policy instrument in US-British relations in both the executive corpus and legislative corpora. Nevertheless, the promotion of the English language never amounted to de jure officialisation attempts before the Civil War, and neither was the Continental Congress willing to support the establishment of a Language Academy. When executive and legislative intentions finally met with respect to the English language, it resulted in the simplification of legal language instead of any kind of refinement or embellishment.

The LPSF reveals that during the early years of American nation-building comprehensive language management efforts intended to be national or at least regional in scope were entirely absent. On the other hand, symbolic remarks (mostly about the expected role of the English language) were frequent. Initially, minority language speakers enjoyed some de facto expediency-oriented rights that gave them the opportunity to become at least somewhat familiar with the goals of the American Revolution and the laws of the new country. Soon, however, these "access" rights were discontinued: minority languages were increasingly treated as a problem, whereas the same languages were considered resources when they appeared in the "foreign language" context of diplomacy or the economy.

Language restrictionism culminated in the English-only law that enabled the state of Louisiana to join the Union in 1812, yet it was far from being the final say in the matter: French language rights were partly recognised in the mid-1840s, but only for a brief while. To this day, Louisiana has remained the only state whose official language was specified as a de jure precondition to admission. It is also true that no other state has been allowed to enter the Union with a clear non-Anglophone majority ever since.

The LPSF shows the swinging of the LP pendulum towards the previously empty quadrant of substantive, general language management in the early 1800s, which was followed by a readjustment after 1815 . The long period preceding the Civil War produced examples to fill each quadrant, yet the crowded substantive, specific quadrant has remained the most salient feature of the LPSF. This fact indicates the practical and pragmatic orientation of legislative attitudes and ideologies: narrowly-focused and frequently ad hoc problem-solving was the most salient feature of American language management efforts throughout the examined decades. 


\section{References}

Adams Papers Digital Edition. 2019. “To the President of Congress, No. 9.” Papers of John Adams, Vol. 10. Massachusetts Historical Society. Accessed January 13. https://www.masshist.org/publications /apde2/view?id=PJA10d115.

Anderson, James E. 2003. Public Policymaking: An Introduction. Boston and New York: Houghton Mifflin Company.

"Annals of Congress." The Library of Congress: American Memory Collection. Last modified May 1, 2003. https://memory.loc.gov/ammem/amlaw/lwac.html.

Crawford, James. 2000. At War with Diversity: US Language Policy in Age of Anxiety. Clevedon: Multilingual Matters.

Derbigney, Pierre. 1804. "Louisianans React to the Louisiana Purchase: Pierre Derbigney's Memorial to the US Congress.” Digital History. Accessed February 4, 2019. http://www.digitalhistory.uh.edu/disp _textbook_print.cfm?smtid=3\&psid=261.

Fillmore, Millard. 1851. "Second Annual Message." The American Presidency Project. Accessed January 21, 2019._https://www.presidency.ucsb.edu/documents/second-annual-message-7.

Galindo, René. 1997. "Language Wars: The Ideological Dimensions of the Debates on Bilingual Education.” Bilingual Research Journal 21 (2-3): 163-201. https://doi.org/10.1080/15235882.1997 .10668659 .

"House Journal." The Library of Congress: American Memory Collection. Last modified May 1, 2003. https://memory.loc.gov/ammem/amlaw/lwhj.html.

Irvine, Judith T. 2012. "Language Ideology." Oxford Bibliographies. Oxford University Press. Last modified January 11, 2012. https://doi.org/10.1093/obo/9780199766567-0012.

Jackson, Andrew. 1834. "Sixth Annual Message." The American Presidency Project. Accessed January 9, 2019. https://www.presidency.ucsb.edu/documents/sixth-annual-message-2.

Johnson, Charles W., and John W. Warner. 2003. "How Our Laws Are Made.” Washington: US GPO.

Johnson, David Cassels. 2013. Language Policy. Palgrave Macmillan.

Johnson, David Cassels, and Crissa Stephens. 2018. "Language Policy and Planning." In The Palgrave Handbook of Applied Linguistics Research Methodology, edited by Aek Phakiti, Peter De Costa, Luke Plonsky, and Sue Starfield, 811-28. Palgrave Macmillan.

"Journals of the Continental Congress." The Library of Congress: American Memory Collection. Last modified May 1, 2003. https://memory.loc.gov/ammem/amlaw/lwjc.html.

Kloss, Heinz. (1977) 1998. The American Bilingual Tradition. Washington, D.C.: Center for Applied Linguistics.

"Letters of Delegates to Congress, 1774-1789." The Library of Congress: American Memory Collection. Last modified May 1, 2003. https://memory.loc.gov/ammem/amlaw/lwdg.html.

Lo Bianco, Joseph. 1999. "The Language of Policy: What Sort of Policy Making is the Officialization of English in the United States?" In Sociopolitical Perspectives on Language Policy and Planning in the USA, edited by Thomas Huebner and Kathryn A. Davis, 39-65. Amsterdam/Philadelphia: John Benjamins.

Macías, Reynaldo F. 2000. "Language Politics and the Sociolinguistic Historiography of Spanish in the United States." In Language in Action: New Studies of Language in Society Essays in Honor of Roger W. Shuy, edited by Joy K. Peyton, Peg Griffin, Walt Wolfram, and Ralph Fasold, 52-83. Cresskill, NJ: Hampton Press.

"Maclay's Journal." The Library of Congress: American Memory Collection. Last modified May 1, 2003. https://memory.loc.gov/ammem/amlaw/lwmj.html.

Monroe, James. 1822. "Special Message to the House of Representatives Containing the Views of the President of the United States on the Subject of Internal Improvements." The American Presidency Project. Accessed January 9, 2019. https://www.presidency.ucsb.edu/documents/special-message-the -house-representatives-containing-the-views-the-president-the-united.

plainlanguage.gov. n.d. "The Plain Language Action and Information Network (PLAIN)." Accessed June 12, 2019. https://plainlanguage.gov/. 
Prucha, Francis Paul, ed. 2000. Documents of United States Indian Policy. Lincoln: University of Nebraska Press.

“Senate Journal.” The Library of Congress: American Memory Collection. Last modified May 1, 2003. https://memory.loc.gov/ammem/amlaw/lwsj.html.

"Senate Executive Journal." The Library of Congress: American Memory Collection. Last modified May 1, 2003. https://memory.loc.gov/ammem/amlaw/lwej.html.

Spolsky, Bernard. 2004. Language Policy. Cambridge, UK: Cambridge University Press.

-. 2009. Language Management. Cambridge, UK: Cambridge University Press.

Sumner, Charles, and George Frisbie Hoar. 1900. Charles Sumner, His Complete Works: With Introduction by Hon. George Frisbie Hoar. Vol. VIII. Boston: Lee \& Shepard.

"The Debates in the Several State Conventions on the Adoption of the Federal Constitution." n.d. The Library of Congress: American Memory Collection. Last modified May 1, 2003. https://memory.loc .gov/ammem/amlaw/lwed.html.

"The Federalist Papers." Congress.gov Resources. Accessed June 2, 2019. https://www.congress.gov /resources/display/content/The+Federalist+Papers.

The Library of Congress. 2019. "A Century of Lawmaking for a New Nation: US Congressional Documents and Debates, 1774-1873.” American Memory Collection. Last modified May 1, 2003. https://memory.loc.gov/ammem/amlaw/.

"The Records of the Federal Convention of 1787." n.d. The Library of Congress: American Memory Collection. Last modified May 1, 2003. https://memory.loc.gov/ammem/amlaw/lwfr.html.

Tiersma, Peter. n.d. “The Plain English Movement.” Accessed January 27, 2018. http://www .languageandlaw.org/PLAINENGLISH.HTM.

"United States Statutes at Large." The Library of Congress: American Memory Collection. Last modified May 1, 2003. https://memory.loc.gov/ammem/amlaw/lwsl.html.

US National Archives \& Records Administration. 2019. "Transcript of Louisiana Purchase Treaty (1803).” Accessed February 2, 2019. https://www.ourdocuments.gov/print_friendly.php?flash=true\&page=tra nscript\&doc=18\&title=Transcript + of + Louisiana + Purchase + Treaty $+\% 281803 \% 29$.

Wells, Kentwood D. 2017. "Fleas the Size of Elephants: the Wonders of the Oxyhydrogen Microscope." The Magic Lantern Gazette 29 (2/3): 3-34. https://library.sdsu.edu/pdf/scua/ML_Gazette /MLGvol29no02-03.pdf.

Washington, George. 1796. "Special Message." The American Presidency Project. Accessed January 9, 2019. https://www.presidency.ucsb.edu/documents/special-message-3536.

Wiley, Terrence G. 1999. "Comparative Historical Analysis of US Language Policy and Language Planning: Extending the Foundations." In Sociopolitical Perspectives on Language Policy and Planning in the USA, edited by Thomas Huebner and Kathryn A. Davis, 17-37. Amsterdam/Philadelphia: John Benjamins.

Wiley, Terrence G., and Haley de Korne. 2014. "Historical Orientations to Language Policy in the United States." LPREN Brief. Washington: Center for Applied Linguistics. http://www.cal.org/lpren/pdfs /briefs/historical-orientations-to-language-policy-in-the-united-states.pdf.

Woolley, John, and Gerhard Peters. n.d. “The American Presidency Project.” UC Santa Barbara. Last modified December 2, 2019. https://www.presidency.ucsb.edu. 